\title{
Regulating extended work shifts: conflict lines and challenges for trade unions ${ }^{1}$
}

\author{
Dag Olberg \\ Fafo Institute for Labour and Social Research, Oslo, Norway \\ dag.olberg@fafo.no
}

\begin{abstract}
This article addresses working time schemes with bighly concentrated work periods and comparatively extended work-breaks. In Norway illustrations are found in both the private and the public sector. These compressed shifts extend the limits regulated in law and collective agreements, yet they have proved popular among groups of employees. The main arguments for applying compressed shifts are presented. Outcomes are discussed in terms of interest heterogeneity and cross-pressure. Institutional settings and actual regulation practices are also addressed in a Nordic context.
\end{abstract}

Key words: compressed working time, interest heterogeneity, trade unions, working time regulation.

Resumen: En este artículo se abordan los esquemas de tiempo de trabajo con periodos altamente concentrados y pausas relativamente extendidas. En Noruega se encuentran ejemplos tanto en el sector público como en el privado. Estos turnos intensivos exceden los límites regulados por ley y convenios colectivos, $y$ sin embargo son muy aceptados por diferentes grupos de empleados. Presentamos los principales argumentos a favor de los turnos intensivos. Los resultados se explican en términos de heterogeneidad de intereses y presiones por ambas partes. La configuración institucional y las prácticas actuales reguladas también se abordan desde un contexto Nórdico.

Palabras clave: jornada intensiva, heterogeneidad de intereses, sindicatos, regulación del tiempo de trabajo.

1 This article discusses data from an on-going research project supported by the Norwegian trade union confederation LO. An earlier version was presented at the IREC 2011conference held in Barcelona. 


\section{Introduction}

During the financial crisis working time issues were on the agenda in most European countries, and various forms of temporary lay-offs and short-working weeks are still being discussed as a means to flexibly adapting to over-capacity. In Norway these measures were also in use during the economic down-turn. Yet, as the effects of the crisis were comparatively mild, after the down-turn discussions and disputes on working time schemes with periodically extended hours («compressed working time») have reentered some labour market segments. Compared to the growing literature on short-time working, with a few exceptions it seems that relatively little has been written regarding compressed working time. ${ }^{2}$ In Norway such schemes have represented challenges for trade unions in both the private and public sector.

This article addresses working time schemes with highly concentrated work periods and extended work-breaks in the building and construction industries on the one hand, and in residential social care units on the other. The justifications for applying such schemes differ in the private and public sector.

In both sectors the lengths of work shifts by far extend the limits regulated in law and collective agreements, and in both cases the extended shifts have proved popular among groups of employees. To the unions this has implied new conflict lines and trade-offs, which make their defense of the standard working day more complicated. Extended work shifts involve problems of interest heterogeneity and cross-pressure, and discussions on regulation level. In Norway differences in central bargaining results in the private and public sector can also be illustrated. These issues are also briefly addressed in a Nordic context, comparing law regulations in Norway, Sweden, Finland and Denmark. Law regulations on exemptions from limits on the length of working time are comparatively similar in Norway, Sweden and Finland. It seems, however, that actual regulation practices differ despite similarities in institutional settings. ${ }^{3}$

\footnotetext{
2 See Wedderburn, 1996, and Tucker, 2006. A number of health-related studies have been conducted; among them Persson et alii (2003) on the effects of the implementation of an 84-hour work week among construction workers building the bridge between Sweden and Denmark in the Malmö region.

3 Data on regulation practices in Sweden and Finland are based on documentation such as law texts and agreements, and on interviews with representatives from the Swedish LO confederation and the union of municipal employees (Kommunal), and the Finish SAK-confederation in June 2011. Interviews with the Danish LO have not yet been conducted. Information on Denmark is based on law texts, agreements and recent research.
} 


\section{Regulations on extended working time in law and collective agreements}

According to the Norwegian Work Environment Act (AML) the general working time limit is nine hours during a 24-hour period, and 40 hours during a seven-day period. The general daily and weekly working time is shortened when the work is shift work, night work or Sundays.

Working time may be counted as an average over certain periods of time («annualization», or average working time over a period of weeks or months). This also typically concerns compressed working time schemes, which do not extend the total annual working time.

Fig. 1. Exemptions from the general working time regulations in the Norwegian Work Environment Act (AML). Compressed working time.

Level of agreement.

\begin{tabular}{|l|l|}
\hline $\begin{array}{l}\text { Agreements approved by large } \\
\text { central unions }\end{array}$ & $\begin{array}{l}\text { General exemptions from the legal framework, work } \\
\text { shifts with specially extended working time (for } \\
\text { instance 84 hours a week) }\end{array}$ \\
\hline $\begin{array}{l}\text { Agreements approved by the Labour } \\
\text { Inspection Authorities }\end{array}$ & $\begin{array}{l}13 \text { hours during a 24-hour period, } 48 \text { hours } \\
\text { during a week. Approval for up to 8 weeks. }\end{array}$ \\
\hline $\begin{array}{l}\text { Agreements between employer, employee } \\
\text { and shop steward }\end{array}$ & $\begin{array}{l}10 \text { hours during a 24-hour period, or } \\
54 \text { hours a week. Collective agreement } \\
\text { required }\end{array}$ \\
\hline Agreements between employer and employee & $\begin{array}{l}\text { 9 hours during a 24-hour period, or } \\
\text { 48 hours a week }\end{array}$ \\
\hline
\end{tabular}

The Norwegian Work Environment Law may be described as detailed, yet relatively flexible as far as working time regulations are concerned. Exemptions from the general framework can be made at several levels, ranging from agreements between the employer and the individual employee (AML $₫$ 10-5 nr. 1), agreements with the shop-steward (AML $\S 10-5 \mathrm{nr}, 2, \S 10-8 \mathrm{nr} .3$ ), or approval from the Labour Inspection Authorities (AML $₫ 10-5 \mathrm{nr} .3$ ). The Work Environment Act also has an «opt-out clause», as it states that large trade unions can decide to approve local agreements that do not respect legal limits (AML $\S$ 10-12 nr. 4). This typically concerns working time schemes with more than 10 hours working time a day and Sunday work. It illustrates a regulation system in which the social partners can agree to exemptions from limits set by lawregulations. The individual employee, with the consent of the shop-steward, can make local agreements with the employer to deviate from limits on working time. Extended working up to 10 hours during the 24-hour period can be decided 
at local level. However, the right to approve agreements on specially extended working time is centralized. According to law, in Norway the large trade unions, in practice unions with national coverage, have this right.

According to collective agreements working time is usually $37 \frac{1}{2}$ hours during the 7-day period, with reduced working time for special types of work, such as shift work. Also collective agreements often contain regulations on alternative working time schemes intended to increase local flexibility. Local agreements can be tried out that extend the framework of a collective agreement as far as both working time and compensation are concerned. These provisions typically state that, on the one hand, the local social partners have to agree, and on the other, that local and alternative schemes have to be approved by the social partners at central level before they are effectuated. These «opt out» clauses in the collective agreements usually refer to the Work Environment Act for regulations on annualization of working time. In private industry several collective agreements contain such clauses on alternative working time schemes. ${ }^{4}$ They open enough for local flexibility, yet they are centrally controlled because local agreements on deviations from collective agreements have to be approved by the social partners at central level. Similar clauses are found in public-sector collective agreements, at both the state and municipality levels. ${ }^{5}$ In social care work, there also exist special central agreements on extended shifts in child- and youth-care units, although they do not cover many institutions or employees. In both the private and public sector these provisions in the general collective agreements have relatively seldom been applied (Olberg, 2010). Alternative local schemes with specially compressed and extended working time in accordance with the «opt out» clauses in labour law have, however, become more common and during the last couple of years have been heavily disputed.

\section{Extended working time in private and public sector}

As the most extreme deviations from law and collective agreements in Norway have to be approved at central (or central/regional) level by trade unions, the number and types of local schemes with compressed working time are relatively well documented.

4 «Feriebilaget om fleksibilitet 2000».

5 Basic agreements (Hovedtariffavtalen $₫ 7.9$, Hovedavtalen $₫ 4-7$ ). 


\subsection{Industryः building and construction}

The number of compressed working time schemes in building and construction has risen steadily from mid 2000. One study notes that from 2004, when these schemes were first systematically documented, the number of local agreements relating to the collective agreements of the industrial union Fellesforbundet rose from about 50 approved schemes in 2004 to about 630 schemes using compressed working time in 2009 (Olberg 2010:24, Stokke et alii 2010:10). These were approved at central LO-level as the daily working time extended to 10 hours (schemes with working time up to 10 hours could be approved or rejected at union level). The shift scheme most commonly used was the «12-9»-scheme (12-day working period with extended shifts, rotating with 9-day work-breaks). The process of handling these local applications has been described as effective; very few local agreements on compressed working time (about 15 percent) were rejected by the union before being approved at central LO-level (Stokke et alii, 2010:10).

\subsection{Public sector: social care}

Also in the public sector the number of centrally approved agreements on compressed working time schemes has risen in recent years. The central union of municipal employees, Fagforbundet, handled about 320 applications in the period 2005-2010. Relatively few local agreements (about 7 percent) were rejected. Most of these local agreements were approved during 2008-2010. The union of employees in hospitals and medical care units, Norsk Sykepleieforbund, approved about 60 local agreements on especially extended working time in the period 2005-2009, and only two local agreements were not approved (Stokke et alii, 2010:8-9). In 2009 the LO confederation at central level also accepted 16 local agreements on compressed working time covering municipal care units (Olberg, 2010:25).

Earlier studies have also documented the use of compressed shifts in the public sector. In 2006 about one-third of the state child care residential units reported that single shifts covering the 24-hour period or a wider time span were used. Typically, the extended shifts would last for up to four 24-hour periods. Compressed working time schemes with longer work periods existed, but they were relatively few (Pettersen and Olberg, 2006). ${ }^{6}$

6 Close to eight out of ten private child care residential care units reported that compressed working time schemes were used (Pettersen and Olberg, 2006). 


\section{Drivers and explanations}

Different driving forces, diverging interests, and structural determinants are reflected in changes in working time arrangements. They frame the possibilities for strategies and choices, and often function as justifications when working time issues are debated and disputed.

In the Norwegian debates on extended work shifts three main arguments have been addressed: economic and practical concerns; concern for clients; and different working time preferences among employees.

\subsection{Economic and practical concerns}

In Norway compressed work shifts are often called «on-shore North Seashifts», referring to working time schemes commonly used in the off-shore oil industry. In land-based building and construction, extended work periods are used when workers have to commute to building sites. As far as the oil industry is concerned, this typically concerns large development sites located in remote and sparsely populated areas. In industry, shift work is used when extended operating time is required during daytime or a 24-hour period. Although not entirely new, during the last ten years alternative forms of shift-systems with extended workperiods and comparatively extended work-breaks have also been applied more often. These schemes typically consist of work periods with extended daily work time for several days (sometimes also combined with night shifts), succeeded by an extended period of work-break. One illustration is the 14-21-rotation system, where two weeks of continuous 12 hour shifts are followed by a period of three weeks off, then two new weeks with extended working time, and so on. Other illustrations of compressed working time in the building and construction industry are shifts with 12 days of work on the building site, followed by nine days off («12-9»), or 11 or 12 days extended work followed by 10 or 16 days work break («11-10», 12-16»).

For the employer, compressed work periods make it possible to extend operating time and use expensive machinery and equipment more effectively. Several of the building and construction projects are located in areas where local firms and local workers do not have the competence and equipment to do these jobs. Therefore, the company who has the building contract brings in its own equipment and workers for the period it takes to complete the projects. 


\subsection{Concerns for clients and users}

The so-called «on-shore North Sea shifts» have also been applied in social care work in the public and private sector. The justification for using compressed shifts is somewhat different. Yet in social care too, external concerns play a role as modern welfare schemes are being exposed to increased demands for the efficient use of resources (Eriksen, 1993). Modern welfare arrangements are also characterized by increased concern for the users of welfare services, the people that receive services from the welfare occupations. In this context a range of alternative working time schemes have been tried out.

It is argued that concentrated work periods for therapists and other staff in residential child welfare units have positive treatment outcomes for the children and youths who are the users of these units. Although not typical for most such units in the public (state) sector, several alternative working time schemes have been tried out, for instance 13-hour and 14-hour shifts, and schemes where the employees live together with the clients/users for several days during the work period, which is then followed by an extended work-break. In social care it is argued that concentrated work periods for therapists and other staff have positive treatment outcomes for the children and youths who are the users of these care units, as compressed working time schemes are believed to provide increased stability and continuity.

Alternative shift schemes are also being tried out in the municipal sector, in units that house patients requiring care for a variety of diagnoses. These alternative shifts mostly consist of some form of compressed working time: for instance, 13 hour or 14-hour shifts for several days followed by a work break. Rest periods are also included in the extended shifts. As in residential child welfare units, it has been argued that extended working time schemes provide increased stability which is beneficial to the clients/users and essential if treatment outcomes are to be positive.

It is also argued that extended shifts in the public sector have positive economic effects, as units need fewer employees. Additionally, some argue that these alternative shifts reduce the extent of involuntary part time work.

\subsection{Working time preferences}

Although alternative compressed shifts constitute only a small part of Norwegian working life compared to ordinary shifts, they have often proved popular among employees. Many employees, in both the private and public sector, have a preference for «block free time», and prefer extended or compressed working 
time. In building and construction this typically concerns workers who have to commute for longer periods and consequently cannot spend their free time with their family and social network.

Compressed working time has also been approved by employers and groups of employees in social care work. Beneficial treatment outcomes for clients and users in residential care units have been part of the background, yet the continuity and stability associated with these schemes have also been reported to improve employees' work environment in these units. ${ }^{\text {? }}$

\section{Extended working time and interest conflicts}

To date, highly compressed working time schemes have only been a small part of working time arrangements, yet in Norway these schemes have caused some disputes in the last couple of years. These disputes have concerned social partners at central and local level, trade unions and their members, and political debate. Conflicting and common interests constitute new lines of conflict. All in all, the central unions are finding themselves in a situation of cross pressure with regards to preserving the standard working day regulations.

\subsection{Common interests}

In some building and construction firms, employers and workers have a common interest in compressed shifts. The firms benefit by extended operating time without paying overtime, and from more effective use of equipment and machinery. The workers have to commute and spend several days at the building sites, but benefit by extended time off at home. In social care too, work groups of employees prefer the compressed shifts, both because of positive treatment outcomes vis-à-vis clients and because of the extended work-breaks.

\subsection{Conflicting interests}

Firms may have conflicting interests regarding extended work shifts, as compressed working time is an element that influences market competition. Firms using commuting workers on compressed shifts and extended operating time will in some cases have advantages vis-à-vis local firms using local workers according to regulations in law and collective agreements. Local employees would normally prefer not to work Sundays; commuting workers often prefer

7 Health issues concerning employees have been part of the discussion on compressed working time. Yet so far few objective studies document negative health effects as result of these types of extended shifts, at least not in the short-term (Olberg, 2010). 
Sunday-work. Unions also have different views on working Sundays as part of compressed shifts.

In an attempt to preserve the standard working day, trade unions have insisted on keeping centrally controlled and relatively restrictive procedures in order to limit the use of compressed shifts. But in so doing they have been criticised by groups of their own members who find compressed shifts popular. In some cases public sector unions have lost members because of the restrictive view on extended working time schemes.

Groups of workers who prefer compressed working time may have conflicting interests vis-à-vis workers who prefer standard working time. Not all workers are in a situation that allows them to work extended shifts. Conflicts of interests for the individual worker may also be noted, as interests concerning income, health, and social time over the life-span have to be balanced.

There have also been disagreements between unions. These disagreements have concerned the use of some types of compressed shifts. One union, for instance, held the view that the «14-21» shift would be too strenuous for its members. There has also been disagreement between private sector unions on whether the use of compressed shifts should be restricted to the building and construction period, or could also be used during ordinary production. In the public sector, employers have argued that an agreement allowing 13-hour shifts would be beneficial in most state-driven child care residential institutions. Municipal employers have also argued that restrictions on extended shifts should be relaxed and decided locally.

At a central level there have been conflicts between employer- and employee organizations on pay and compensation and, especially, on the length of work breaks (as this may influence the length of the total annual working time).

In the political debate the provisions in the Work Environment Act that enable the large unions to approve or reject exemptions from the law are disputed. These debates, centered on a right-left axis, concern the power of large unions in making decisions and establishing regulations. Critics argue that decisions on compressed working time should be based on local agreements, and that these agreements should be approved by the local Labour Inspection Authorities, not by the large unions at a central level. The employer confederations have also argued that the legal provisions on exemptions from limits on the length of the working time provide a monopoly situation for unions, and that the unions use this situation to shorten the standard working time without this being an issue in the ordinary bargaining rounds. In the industrial sector, the conflict was sharpened and has only recently been solved, so far by a central collective 
agreement that regulates how the trade union should practice its right to sanction local agreements on compressed working time. In the public sector no such agreement has been reached.

\section{Regulations on extended working time in Sweden, Finland and Denmark}

Norway, Sweden and Finland are similar as it is accepted in legal regulations that exemptions from working time regulations can be made. Denmark is the deviant case in this context as the work environment law does not give similar clear guidelines. The issue seems to be left to the local social partners and the collective bargaining system to handle.

\subsection{Sweden: decentralized practices}

The Swedish Working Time Act states that exemptions from law provisions, or even the entire Working time Act, may be made thorough collective agreements. It gives the unions considerable power at central level as it is stated that such collective agreements have to be approved by «a central employee organization» $(\$ 3)$. As in Norway, preliminary agreements are to be made locally by the local parties (not by the employer and the individual employee) and then approved at union level.

According to interviews with the Swedish LO and the union of municipal employees Kommunal, compressed working time was not something the LO or the unions saw as a pressing issue. ${ }^{8}$ It was not debated, as it is in Norway, and the employers did not press for changes in regulations. The Working Time Act gives «central employee organizations» the right to make exemptions from regulations in the law; in practice this is left to the unions, which again delegate this right. This is described as quite usual, and this delegation process is in some sectors also decentralized to firm level. In the municipal sector, though, it is not the local shop steward who signs the local agreements. These local agreements are always signed by a union representative who holds the position of ombudsman. The Swedish LO and the unions assume that general concerns regarding trade union interests in health, safety and wages are assured in the local agreements. In practice these local agreements often reflect the duration of a collective agreement (or last for a shorter period of time). As a collective agreement often lasts for two years, the limit of one year set in the Working Time Act seems not to be reflected

8 Stockholm, June 15th 2011. 
in local practices. The local agreements on alternative working time schemes are not approved or rejected at central LO or union level, and there seem to be no central records or documentation on the extent or variation of alternative schemes, including compressed work. Although the law prescribes a centralized procedure, Swedish practices are decentralized.

\subsection{Finland: decentralization and central control}

The Finnish Working Time Act is comparable to provisions in both the Norwegian Work Environment Act and the Swedish Working Time Act in several aspects. Yet it is stated that country-wide employer- and employee organizations can agree on working time schemes that deviate from provisions in law.

An interview with the Finnish SAK-confederation indicated that local bargaining and local agreements within the framework of collective agreements have steadily been becoming more common. ${ }^{9}$ As collective agreements mainly give general guidelines, there is a wide scope for variations in local agreements. ${ }^{10}$ There are, however, considerable variations between sectors. The collective agreement regulation in the food processing industry is described as tight, controlled by the union and with little or no scope for local variations. From the SAK's point of view, the public sector is fairly well regulated as far as working time schemes are concerned, with guidelines for time-bank schemes in collective agreements and public regulations. Compressed working time does not seem to be an issue that is much debated in social care work. Industry, and the Metalli union, is at the opposite end of the scale. Here the scope for local variations in local agreements is described as very wide, as a result of outsourcing and the unions' central and real fear of job losses. Finnish industrial firms have already moved production to other countries with lower costs, among them Estonia and Lithuania. A large part of Finish industry is export-oriented, and firms seek flexibility and local variations in order to adjust to global market competition. The unions, in turn, are pressed and willing to comply with the employers' demands for more local variations in order to retain jobs. Although the Finnish Working Time Act leaves it to the central employer and employee organizations to make exemptions from the law, the collective agreements that make such exemptions possible are foremost. These agreements vary, as some are restrictive (for example, food processing) while others leave it up to the local parties to sign local agreements. Such local agreements may be reported to the central union, but they do not have to be. It is assumed that in industry there are hundreds of local working time

9 Helsinki, June 23rd 2011.

10 See also Asplund, 2007. 
agreements, yet no central records are kept on the extent or variations by SAK or the unions. Generally there seems to be more variation and, all in all, more decentralization but also fragmentation, as some industries are still characterized by centralized regulation in collective agreements. There also seems to be less cooperation between labour organizations.

\subsection{Denmarkः organized decentralization}

The chapter concerning working time regulations in the Danish Work Environment Act is shorter than the chapter in the Norwegian act. Provisions for exemptions by government and the labour inspection authorities are mentioned, yet it is assumed that shop stewards and firms agree before exemptions are made, which indicates that the Danish system is based on agreements and decentralization. In both the municipal and state sectors, central bargaining resulted in a general agreement on decentralized working time agreements. ${ }^{11}$ The intention was to prepare for local agreements that took into account the needs of local institutions and employee preferences, including work-life-balance concerns. Local agreements can deviate from working time regulations in collective agreements, yet it is understood that work environment provisions and the EU Working Time Directive should be respected (although deviations from the directive in some cases can also be made). The general agreement on local agreements is short and not detailed. It presupposed that local and alternative working time schemes should be evaluated, «for instance after a period of two years». In practice, however, it seems that they are evaluated after somewhat longer periods of time. Evaluations have been positive, and have been discussed by the central partners before the general agreements on decentralized working time agreements were prolonged. In the state sector a similar general agreement has been in force since 1999. According to this central agreement, local agreements can also deviate from, or supplement, regulations in collective agreements. So far, these regulations, which govern working time schemes other than local agreements (illustrating the Danish system of «organized decentralization»), seem not to be disputed. ${ }^{12}$

In Danish industry local agreements on working time are widespread. More than eight out of ten firms have concluded one or more than one agreement, predominantly on flexi-time and shift work (Ilsøe 2009:53). A survey-based

11 «Rammeaftale om decentrale arbejdstidsaftaler» June 24 1999, April 1999.

12 In industry, the collective bargains (2004-2007) contain a short protocol regarding working time on oilrigs. It states that rest periods can be delayed or limited to 8 hours, work periods extended to 28 days by written agreements between the individual worker and local management, local agreements can be signed for work periods consisting of, for example, 14-day work periods followed by 21-day rest periods off-shore (COindustri/ Dansk industry, 2004:21). 
study recently indicated that flexi-time agreements had been made in more than four out of ten firms, and shiftwork agreements in a third of firms (Ilsøe, 2011:11). According to this study compressed work weeks and extended shifts (12 hours) are used in approximately two out of ten firms (survey-answers from shop stewards indicate a somewhat wider coverage). Compressed work weeks can be of various types, but the typical format is a working week of three to four days with extended hours. Such schemes do not usually affect all the workers in a company; they typically cover a minority (Ilsøe, 2009:78). Yet there are interesting developments regarding flexi-time and shift work on the one hand, and shift work and compressed working time on the other ${ }^{13}$

Interest heterogeneity is also an issue discussed in the Danish context of organized decentralization. Ilsøe $(2011: 17)$ points out that shop stewards have the challenge of mediating disagreements in an increasingly diversified work force, and that they face coalition problems because of varying working conditions and representation problems because minorities of workers may find that their interests are not covered by collective agreements.

\subsection{Duration and level of approval}

Summing up, in both Norway and Sweden the Work Environment Act $(\mathrm{N})$ and the Working Time Law (SE) explicitly leave it up to central unions to approve (or reject) agreements on exemptions from the legal regulations on limits on working time. The Finnish Working Time Act states that central trade unions and central employer organizations can agree on exemptions from the law-based limits. In this context Denmark is a deviant case. In Norway the practice of approving specially compressed working time is centralized. Each local agreement is approved individually at a higher union or LO level. In the other three countries practices are more decentralized and based on approval in advance.

There are also differences concerning duration. Swedish legal regulations state that exemptions from the law can be made for up to one year. In Norwegian and Finnish law, the duration for exemptions is not limited in time. The time limits stated in Swedish law are, it seems, not followed up in practice, as local agreements on extended working time usually follow the duration of a collective agreement. Although no time limit is stated in Norwegian law, the LO confederation has

13 «Further, an interesting development can be found with regard to new forms of shift work. Agreements on traditional shift work are now increasingly supplemented (or maybe replaced) by agreements on staggered hours, compressed workweeks and 12-hour shifts. Case studies have shown that the latter two can be attractive alternatives for some groups of workers who prefer more days off in a row for hobbies, summer house visits, etc.» (Ilsøe, 2011: 11). 
chosen a practice by which exemptions in local agreements are approved for up to one year.

The most striking difference concerns the level of approval. The countries differ in terms of which organizational level decides to approve or reject local agreements on specially extended working time. In Norway the final decision is made by the LO, or by unions, at central level. The LO also keeps central records of all local agreements that are approved. The Norwegian union of municipal employees (Fagforbundet) accepts or rejects local agreements at regional level, but respecting central guide lines. Sweden, Finland and Denmark, on the other hand, in general follow more decentralized procedures. In these countries there seems to be no central control or central documentation at LO-confederation or union level. As a consequence, it is difficult to state how many local agreements on compressed working time are being signed, and in which sectors and firms compressed working time schemes are being used. Approvals are being given in «advance», which indicates that the confederations and unions at central level assume that the basic concerns stated in the collective agreements are also assured in local agreements on extended working time. Compared to these more decentralized practices in Sweden, Finland and Denmark, the centralized approval system of the Norwegian LO and Norwegian unions represents the deviant case.

Fig. 2. Exemptions from working time regulations in labour law. Four Nordic countries.

\begin{tabular}{|l|c|c|c|c|c|}
\hline Norway & $\begin{array}{c}\text { Actor deciding } \\
\text { exemptions }\end{array}$ & Organization level & Duration & Control & $\begin{array}{c}\text { Conflict } \\
\text { level }\end{array}$ \\
\hline Sweden & Large unions & $\begin{array}{c}\text { Central } \\
\text { (Central/ } \\
\text { regional) }\end{array}$ & Up to 1 year & $\begin{array}{c}\text { Central } \\
\text { (regional) }\end{array}$ & + \\
\hline Finland & $\begin{array}{c}\text { Large employer- } \\
\text { organizations } \\
\text { and unions }\end{array}$ & $\begin{array}{c}\text { Varied } \\
\text { (Sector) } \\
\text { local }\end{array}$ & $\begin{array}{c}2-3 \text { years } \\
\text { (collective } \\
\text { agreements) }\end{array}$ & Local & - \\
\hline Denmark & Social partners & Local & - & $\begin{array}{c}\text { Varied } \\
\text { (Central) } \\
\text { Local }\end{array}$ & - \\
\hline
\end{tabular}




\section{Discussion: similarities in institutional frameworks and different regulation practices}

In the Nordic context, relatively similar institutional regulations on extended working time schemes in labour law and collective agreements are followed by quite different regulatory practices by unions.

In the Norwegian context working time schemes with specially extended work periods are controlled centrally by the unions and coordinated and sanctioned by the LO confederation. Norway, Sweden and Finland have legal regulations that centralize the right to make agreements that deviate from the law. Denmark is the deviant case.

In Sweden, Finland and Denmark, the institutional set-up and actual practices concerning exemptions from the legal limits are decentralized. In this context Norway is the deviant case, as procedures and approvals of exemptions are centralized.

Moreover, in Norway regulations on extended working time schemes are contested and debated. In the other three countries informants did not indicate that such schemes were controversial.

What explanations are there for these different practices in relatively homogeneous regulatory frames? One explanation may be the Norwegian oil industry. The off-shore activities at the oil rigs in the North Sea have made use of compressed working time schemes for decades. For natural reasons workers had to be brought out to the platforms. Because of both distance and cost, daily commuting was never considered. The Norwegian oil industry is centrally regulated (law-regulations and regulations by the labour inspection authorities), as far as health and safety are concerned.

Since the 1980s, the oil industry has also largely engaged in on-shore activities, including the construction of large industrial sites containing oil and gas refineries. Because these industrial sites were often located in distant and sparsely populated areas, and because employers and workers in the industry were already familiar with the compressed shifts, there may have been a «spillover» effect, as working time schemes associated with the North Sea shifts were also applied on-shore.

In this context it seems probable that centralized practices regarding regulations of health and safety, including working time issues, were continued in the new land-based setting - a possible second «spill-over» effect regarding regulation. The exemption-clauses in the Norwegian Work Environment Act originated in the mid-1980s. Large development projects relating to the oil 
industry were an important part of the historical background, as the rightcenter government indicated that more flexible regulation was to be established, one way or the other. One interpretation could be, then, that the right of central unions to approve exemptions from legal regulations did in practice constitute an opportunity for flexibility for employers. Employers were provided with a way out of legal regulations and collective agreements, but at the price of tight central trade union control. As this trade-off was the only way they could rapidly achieve the flexibility of the specially extended shifts, they were willing to pay the price - which included trade union control. This is now being disputed, as employer confederations and some political parties want changes to be made to the law so that the decision is left to the local parties and labour inspection authorities. However, in Norway the LO confederation and the unions have so far had the power to maintain central control regarding extended work shifts.

Although they are exposed to cross pressure, the unions seek to defend the standard working day because they regard local schemes with extended shifts as something which, if not centrally controlled, could contribute to undermine the standard working day regulations. They argue that they want to maintain comprehensive concerns to protect workers' interests in the long run. However, these are concerns that some of their members do not necessarily share, and they seek alternative working time schemes that suit their individual needs here and now.

\section{References}

Asplund, Rita (2007). «Finland: Decentralisation tendencies within a collective wage bargaining system».Discusion papers, 1077. Elinkeinoelämän Tutkimuslaitos. Helsinki: ETLA.

CO-industri / Dansk industry (2004). Industriens Organisationsaftaler 2004-2007.

ERIKSEN, Erik Oddvar (1993). Den offentlige dimensjonen. Verdier og styring av den offentlige sektor. Oslo: Tano.

Ilsøe, Anna (2011). «The Flip Side of Organized Decentralization», British Journal for Industrial Relations, doi.1111/j.1467-8543.2011.00875. London: Blackwell.

ILsøE, Anna (2009) «Decentralisering i praksis - en spørgeskemaundersøgelse af lokalaftaler om løn og arbejdsvilkår i industrien». Faos Forskningsnotat, 103. Copenhagen: Faos. 
Olberg, Dag (2010). «De utvidete arbeidstidene. Om regulering av innarbeidingsordninger, langturnus og langvakter». Fafo-rapport 2010: 35. Oslo: Fafo.

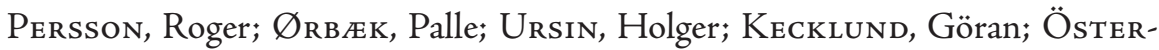
Berg, Ka; Åkerstedt, Torbjörn (2003). «Effects of the implementation of an 84-hour workweek on neurobehavioral test performance and cortisol responsiveness during testing», Scandinavian Journal of Work, Environment and Health, 29 (4):261-269.

Pettersen, Karen-Sofie; Olberg, Dag (2006). «Arbeidstid i barneverninstitusjonene og behandlingstiltaket MST». NOVA-rapport 8/2006. Oslo: NOVA.

Stokke, Torgeir Aarvaag; Øivind M. Berge, Åsmund Seip (2010). «Arbeidstidsordninger som fraviker arbeidsmiljøloven. Utvikling, omfang og praksis». Fafo-rapport 2010:42. Oslo: Fafo.

Tucker, Philip (2006) «Compressed working weeks». Conditions of Work and Employment Series, 12. Geneva: International Labour Office.

Wedderburn, Alexander, ed. (1996) «Compressed working time». BEST nr. 10 1996. Bulletin of European Studies on Time. Brussels: European Foundation for the Improvement of Living and Working Conditions. 